A SMALL BOY AND OTHERS 


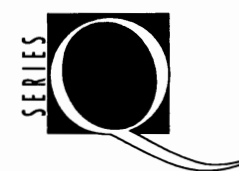

Edited by Michèle Aina Barale, Jonathan Goldberg, Michael Moon, and Eve Kosofsky Sedgwick 


\section{A SMALl BOY AND OTHERS}

Imitation and Initiation in American Culture

from Henry James to Andy Warhol

BY MICHAEL MOON

Duke University Press ^ Durham and London 1998 
๑ I998 Duke University Press

All rights reserved

Printed in the United States of America on acid-free paper @

Typeset in Quadraat by Tseng Information Systems, Inc.

Library of Congress Cataloging-in-Publication Data

appear on the last printed page of this book. 
To Marcie Frank and Eve Kosofsky Sedgwick 
